\title{
SPECIFIC FEATURES OF DEVELOPMENT OF TOURISM WITHIN THE AREAS NEIGHBOURING UPON THE POLISH EASTERN BORDER
}

\author{
MAREK WIĘCKOWSKI \\ Institute of Geography and Spatial Organization \\ Polish Academy of Sciences \\ Twarda 51/55, 00-818 Warsaw, Poland \\ e-mail:marekw@twarda.pan.pl
}

\begin{abstract}
The paper presents selected problems of development of tourism within the areas neighbouring upon the Polish eastern border. Currently the boundaries with Belarus, Ukraine and the Kaliningrad district of Russia constitute the outer boundaries of the European Union and the Schengen zone, with strengthened protection and increased difficulty of crossing them. Borders determine the nature of the tourist space and its elements that will develop in frontier regions. First of all the borders constitute spatial barriers for tourism development and movement. On the other hand they often coincide with valuable natural landscapes and a numerous historical and cultural attractions. They possess, therefore, a high tourist potential. In the paper the influence of the most important elements on tourist attractiveness of a border-adjacent area are presented in the case of eastern border area of Poland. Tourism, in the vicinity of eastern boundaries of Poland, is generally characterised by poor tourism-related development and lack of tourist traditions, as well as low degree of recognition as tourist destination. In the transboundary setting, tourism within the eastern borderland is based almost exclusively on the price differentials. These are both trade and transit, as well as short tourist visits.

Key words: tourism, border, Poland, Schengen zone
\end{abstract}

\section{INTRODUCTION}

Border-adjacent areas usually constitute peripheries from the socio-economic point of view. They often coincide with valuable natural landscapes and are frequently relatively little transformed by the human economic activity. Additionally, they tend to feature numerous historical and cultural attractions. They possess, therefore, a very high tourist potential. Yet, the potential itself is not sufficient for the actual development of tourism. Besides, it is limited by the neighbourhood of the boundary 
and by its significant function of a spatial barrier. This function entails the existence of a discontinuity in the social and economic space (including tourist space), and limits the transboundary flows of people. For the entire "eastern" boundary of Poland, the function that the very boundary plays, is essential. Since 2004, except for the 100-kilometre segment of the boundary with Lithuania, this is the outer boundary of the European Union, and then, since, 2007-additionally the outer boundary of the Schengen zone.

\section{CONDITIONS FOR DEVELOPMENT OF TOURISM IN BORDER AREAS}

State boundaries are important for the economic development of areas that neighbour upon them. They are convenient locations for industrial plants and for tourism (Pradeau 1994) and for protected areas (Young, Rabb 1992; Kałuski 1994; Denisiuk et al. 1997; Więckowski 1998). The social and economic differences between the neighbouring areas across the border bring also about the existence of the illegal traffic of goods and people. Tourism is, therefore, one of areas of human activity, which develop in the vicinity of the borders. The boundaries, separating different political, administrative breakdown or spatial development types, influence the development of tourism through, in particular, motivation and stimulus to taking decision on travelling, development of tourist infrastructure, marketing and promotion, and regional branding (Więckowski 2009). Boundaries and their role, especially as barriers, are significant first of all for the flows and for spatial development. A description of relations between tourism and political boundaries was proposed by J. D. Timothy (2002), who distinguished boundaries as: barriers, destinations and elements modifying tourist space. Political boundaries are barriers, especially for the flow of people, but, at the same time, they constitute a tourist attraction. Tourists, coming to the border-adjacent areas, contribute to the emergence of tourist developments. Yet, tourist infrastructure might develop in any place whatsoever in order to attract tourists. Boundaries entail also a modification of the tourist space. Besides, boundaries predestine to fulfilment of certain functions of spatial development and to definite types of tourism.

The development of border areas is influenced primarily by the fact of existence of political boundaries and the function they play. The general transformations that have been taking place in Poland resulted in the changes of the course of boundaries (as the consequence of the World War II), of their function in the consecutive decades, and increase of mobility and flows across the boundaries, especially after 1989. The changes in these processes were brought about by a number of elements, among which the most important were political decisions (ideology), both with respect to the border-adjacent areas and, in particular, for the transboundary relations. The consequences of these decisions are the changes in location and functions of the political boundaries. This bears significance for the directions of economic 
development and influences space, changing the capacities of its development, due to changes in the capacity of using resources. These capacities, as well as the directions of economic development mutually impact upon the social development (Figure 1).

Political decisions<smiles>C1CCCC1</smiles>

Changes in the course of borders

Changes in the function of borders

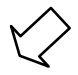

Economic development directions

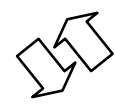

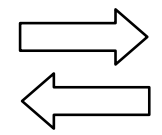<smiles>[CaH]</smiles>

Space as resource

\section{Social development}

Figure 1. Conditions for development of border-adjacent areas

Source: own elaboration.

The specificity of the border areas for the development of tourism may be presented from the point of view of classification into main elements, their significance and domains of influence. A number of interdependences can be indicated, proper for individual domains of science, including economic, political, social, symbolic and natural domain.

In the economic domain the development of tourism is the impulse for economic growth, and convenient conditions exist within the border areas for tourism development. The boundary is a barrier, but, due to the change in its functions, it may become a filter-border or a zone-border. Owing to the integration processes and increase of intensity of flows, the boundary becomes a factor of growth. There may arise an effect of synergy between the boundary and tourism.

In the political domain the primary aspects are changes in the course and functions of the boundaries. In integrating Europe there is also a transfer of competence towards the lower levels of administration. Transboundary cooperation is being developed, along with joint planning and elaboration of development strategies. Besides, in the European Union the border areas and, in particular, tourist activity in these areas, are subject to specific access to financial means (PHARE, INTERREG, European Territorial Cooperation).

In the social domain the transboundary exchange and development of tourism are conducive to changes in norms, behaviour patterns and ideas, and to openness and tolerance. The concept of tourism as an encounter of cultures refers to one of 
the basic sociological theories-the theory of exchange. In the process of interaction tourists and the receiving community exchange information and values. The scale and the character of changes depend mainly upon the features of tourists, properties of the receiving community, and the mechanism of interaction of the two populations (Przecławski 1996).

In the symbolic domain the boundary is nowadays both a symbol of a barrier, and also of integration, i.e. a linking element. The boundary, similarly as tourism, is the element of globalisation, and both remain under its significant influence, which is expressed through the processes of integration, modernisation, and increase of intensity of flows. Yet, regional and local identities remain an important element of development of the border-adjacent areas, and the need for pronouncing the differences, play the role of the necessary factor for the development of tourism.

In terms of nature, isolation of the border areas entailed their relatively better natural (environmental) condition. This, in turn, constitutes a significant asset for the development of tourism based on little transformed and attractive natural environment. High quality and unique - exceptional—character of these areas is expressed through the relatively high number of legally protected nature areas, including national parks, being the biggest attractions. The closeness of similar areas across the border causes that their joint protection increases the rank, the surface area and the attractiveness of these areas. Nature protection has become, actually, the main domain of the transboundary cooperation.

\section{CHANGES OF BOUNDARIES AND THEIR FUNCTIONS}

The present-day boundaries of Poland were established after the World War II, with small modifications in later years. There was a sharp decrease of the number of neighbouring countries-from seven to three (Eberhardt 2004). Territorial shifts of Poland were highly significant. The length of boundaries decreased, as well, shrinking from $5529 \mathrm{~km}$ in 1938 to 3560 in 1945, that is-by $1969 \mathrm{~km} \mathrm{(35.4 \% ).} \mathrm{The} \mathrm{ma-}$ jority of boundaries, which appeared after the World War II, were new at that time (the Polish-German boundary on rivers Oder and Nysa Łużycka, and almost entire boundary between Poland and the Soviet Union). In the consequence of the political decisions and changes of boundaries, large migration waves followed, population in border towns dropped, the settlement system changed, as did social and economic connections, the transport networks were cut across, which entailed increased isolation of the neighbouring areas. The regional centres in Poland, whose hierarchical rank and the reaches of market catchments changed, owing to the post-war shifts of boundaries, are: Przemyśl (a centre that was ruined by the new course of the boundary—it found itself a dozen kilometres from the border), Rzeszów and Zielona Góra (the centres, which emerged owing to the new border), Szczecin (a centre, whose catchment area shrunk), and Olsztyn (a centre, whose catchment area expanded) 
(following Rykiel 1991). The consequences of changes were also visible in tourism. Due to appearance of new boundaries some areas have been cut across by the state boundaries (like Warmia and Masuria, Białowieska Forest, Roztocze Hills), got separated away from the natural customer markets (for instance, Sudety Mts. stopped to be the primary goal of travels for the inhabitants of Dresden and Berlin, while Roztocze-for the inhabitants of Lwów), or were purposefully depopulated in order to deepen isolation, so that the formerly existing tourist function has disappeared (e.g. the areas in the upper basin of San river).

In 2004, when Poland became a member of the European Union, its boundaries took on the status of two main types. The boundaries with Germany, Czechia, Slovakia and Lithuania, as well as almost entire sea boundary, became the internal boundaries of the European Union. For the areas neighbouring upon these boundaries the development of tourism is and shall be easier and subject to a lesser impact from barriers. The boundaries with Belarus, Ukraine and the Kaliningrad district of Russia became the outer boundaries of the European Union, with strengthened protection and increased difficulty of crossing them. These same boundaries, became three years later the outer boundaries of the Schengen zone. Poland entered the Schengen zone on December 21st 2007, along with other eight countries, which were among those that joined the European Union in 2004. Polish boundaries with Germany, Czechia, Slovakia and Lithuania have thereby become the open internal borders of the European Union and the internal borders within the Schengen zone. Currently (in 2009) all the boundaries between Poland and the countries of the European Union have been for several years already the zones of contact, while the outer borders have become closed again (though not as tightly as before 1989).

\section{POSSIBILITIES OF TRANSBOUNDARY USE OF THE AREA}

Transboundary tourism constitutes an element of international tourism, while the transboundary tourist space exists on both sides of the border and is accessible to persons coming from the neighbouring country. In this case tourists, tourist infrastructure, tourist attractions etc. must have transboundary character, that is-transgressing the boundary. The transboundary tourism may be understood as:

- all kinds of tourism that allow for using the assets on the territories of at least two neighbouring countries;

- forms of tourism associated with specific qualities and tourist infrastructure, existing within the border-adjacent areas (usually featuring specific identity, complementarity, characteristic economic aspect, and price differentials), in the perspective of border crossing;

- tourism, whose goal is to visit and cognise the area "on the other side" of the border;

- tourism, whose goal is to undertake travel in the setting of two neighbouring countries, with crossing of the border, as the necessary distinguishing element. 
It is, of course, difficult to uniquely define the notion of transboundary tourism, even though it is present in the scientific literature (Meyer 2001; Studzieniecki 2004; Potocki 2009). Transboundary tourism might be understood as tourism inside a region, which is composed of territories of two or more countries, and is situated on two sides of the respective border, the motivation for this tourism being the tourist product of the particular region (Studzieniecki 2004). On the other hand, J. Potocki (2009) proposed a definition, in which the essence of the transboundary tourism is "the stay of a tourist within the border area, linked with crossing the border and using the services of at least two neighbouring countries" (Potocki 2009).

One of the key issues, associated with the tourist function of the border-adjacent areas is the one of tourist attractiveness. It had been held previously that the tourist attractiveness of a place depends upon its tourist qualities or only the existing tourist infrastructure. According to the model of tourist attraction (Leiper 1990; Lew 1987; Richards 2002) the force, with which a place attracts tourists does not depend uniquely upon its tourist qualities. The influence of the most important elements on tourist attractiveness of a border-adjacent area is shown in Figure 2.

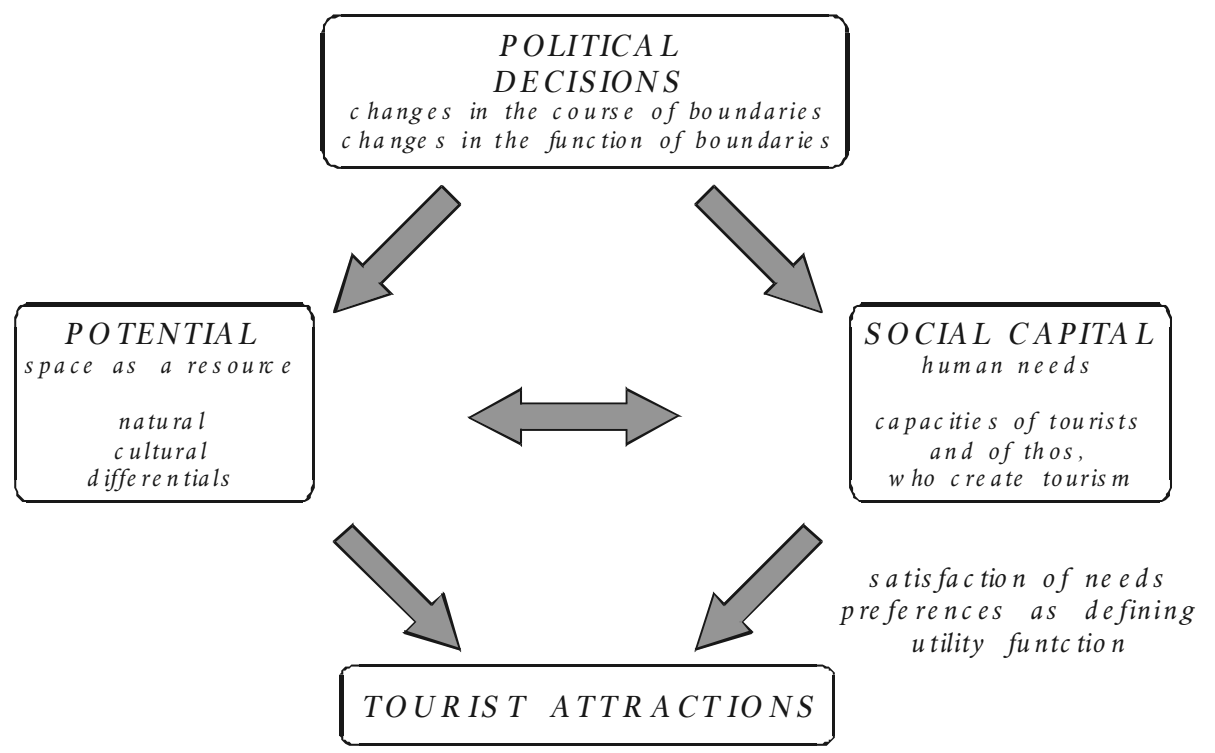

Figure 2. Influence of the most important elements on tourist attractiveness of a border-adjacent area

Source: own elaboration.

It is admitted nowadays that an important element, having influence on the tourist attractiveness of a location, is the manner, in which tourist traffic is organised, and especially promotion and tourist service. For the transboundary use of an area the necessary conditions are: border crossings, tourist routes reaching border crossings, tourist routes along the border, made available to tourists from the neighbour- 
ing country, appropriately distributed and located accommodation infrastructure, coherent transport system, including coach, van and railway connections, jointly agreed upon tourist information, and-for purposes of development of international tourism-joint tourist offer and marketing (Więckowski 2004). The contemporary approach emphasises also the symbolic dimension, which finds expression in the mean-ing, conveyed through the texts or signs, ascribed to the tourist attractions and areas, facilitating social consumption of tourist qualities. That is why it is so important to create new products, increasingly comprehensive, for which a boundary provides ample possibilities. National parks start to be the tourist icons and many countries promote them as attractions that are the tourists' musts. In many cases the main magnet is the national park as a marketing product. In other cases the sole cause for visiting a national park is its unique character (Boyd 2004, p. 473). In this context the national parks, situated in the vicinity of the eastern boundary of Poland have an opportunity for becoming an essential element of the tourist space of the borderland. In the opinion of many authors the entire eastern Polish borderland has a high natural potential for tourist development (Kałuski 1993, 1994; Rąkowski 2000; Palmowski 2007). A number of transboundary parks have been proposed across the area of the entire eastern borderland (Rąkowski 2000; Miszczuk 2007). The area of the Carpathian Mts. in Ukraine possess, as well, a high potential for the development of health resort type of tourism (Krawczyk 1999), but a poor development of the accommodation and general infrastructure hampers the proper functioning of this area and the attraction of customers, especially from Poland. The most important tourist area in the vicinity of the Polish-Ukrainian boundary is constituted by Bieszczady Mts. This is the most interesting, best developed and largest reception area of the classical tourist traffic. This area is actually located at the interface of three countries: Poland, Ukraine and Slovakia. Its most important feature is high quality and originality of the natural environment of the mountains, owing to which it is subject to legal protection in the form of three national parks ${ }^{1}$ and one entity, encompassing the entire area of these national parks, as well as areas beyond them, as the International Biosphere Reserve "Eastern Carpathians". For Poles, the western parts of Ukraine and Belarus, as well as Lithuania, have the features of the receiving area for sentimental tourism. Yet, travels of this type, which were popular in the 1990s, quite soon stopped being attractive. Satisfaction of curiosity was quick, often just with a single trip.

The outer boundaries of the Schengen zone in Poland have numerous assets for creating valuable tourist attractions and tourist products, based on them. The most important tourist attractions, existing either on the very border or crossing it, include: - bicycle and walking paths (which constitute very often a tourist product developed by the municipalities from their own budgets, and largely owing to the European means);

1 On the territory of each of the three countries a national park is located within this area. On the Polish side: the National Park of Bieszczady Mts., on the Ukrainian side-Uzhanski National Park, and on the Slovak side: Poloniny National Park. 
- cross-border walking and bicycle tourist routes, in cases of borders on the rivers, crossing them over the bridges;

- three-country-border points (a fashionable product, but its attractiveness is enhanced by the possibility of crossing the respective borders);

- natural environment, with a specific possibility of developing eco-tourism;

- cultural elements (museums, historical monuments, etc.), cultural events;

- use of services (catering, accommodation-with the possibility of constructing respective facilities in a close vicinity of the border).

The existing elements, which might find themselves in the sphere of interest of tourists, are also those that result from the specific features of the border and the areas neighbouring upon the border (walls, defence lines, fortresses, castles). Yet, these facilities are, as of now, only marginally used for tourist purposes.

\section{TOURIST TRAFFIC}

There is definite tourist traffic on the areas neighbouring upon the eastern boundaries of Poland, but, compared to other Polish border areas, this traffic is smaller. Besides, the majority of the transboundary traffic (which can be designated as the transboundary mobility) is constituted by trips associated with trade, transit and job-related travels. A vast majority of the cross-border traffic consists of travels, which last just a couple of hours (up to maximum of 24 hours). Yet, compared to other nations, the highest percentage share among the foreigners, who stay in Poland Table 1. Comparison of the number of times the border was crossed, tourists and tourists having used the official hospitality industry in 2008

\begin{tabular}{|c|c|c|c|c|c|}
\hline \multirow[b]{3}{*}{$\begin{array}{c}\text { Country } \\
\text { of origin } \\
\text { of the visitors }\end{array}$} & \multirow{3}{*}{$\begin{array}{l}\text { Number } \\
\text { of times } \\
\text { the border } \\
\text { was crossed } \\
\text { (in million) }\end{array}$} & \multicolumn{4}{|c|}{ Number of tourists } \\
\hline & & \multicolumn{2}{|c|}{ Totals } & \multicolumn{2}{|c|}{ Using the official hospitality industry } \\
\hline & & $\begin{array}{l}\text { Number } \\
\text { (in million) }\end{array}$ & $\begin{array}{l}\text { Share in } \\
\text { the number } \\
\text { of all foreigners } \\
\text { from a given } \\
\text { country (in \%) }\end{array}$ & $\begin{array}{l}\text { Number } \\
\text { (in million) }\end{array}$ & $\begin{array}{l}\text { Share in } \\
\text { the number } \\
\text { of tourists from } \\
\text { a given country } \\
\text { (in \%) }\end{array}$ \\
\hline Totals & 59.9 & 13.0 & 21.62 & 4.1 & 31.22 \\
\hline Germany & 34.6 & 4.8 & 13.80 & 1.1 & 23.9 \\
\hline Czechia & 7.8 & 0.2 & 2.30 & 0.08 & 45.11 \\
\hline Ukraine & 3.3 & 1.6 & 46.69 & 0.1 & 8.93 \\
\hline Belarus & 2.1 & 0.9 & 40.85 & 0.07 & 7.62 \\
\hline Slovakia & 3.7 & 0.1 & 2.14 & 0.04 & 45.5 \\
\hline Russia & 1.3 & 0.4 & 31.78 & 0.1 & 25.85 \\
\hline Lithuania & 2.0 & 0.7 & 36.01 & 0.1 & 16.03 \\
\hline
\end{tabular}

Source: own elaboration on the basis of data from the Central Statistical Office (GUS), the Border Guards and the Institute of Tourism. 
longer than one day, is noted among the citizens of countries bordering upon Poland from the East: Lithuanians, Belarusians, Ukrainians and Russians. This may be due to several factors-a part of them are persons coming to Poland for trade purposes (and those are not proper tourists) and to work, moving to locations situated farther away from the boundary. For a significant part of this group Poland is a transit country on their way to Western Europe (mainly for Lithuanians).

For Poles, trips to the countries of the former Soviet Union are decidedly less attractive. Their trips are mainly undertaken for trade purposes. The share of proper tourist traffic (with duration exceeding 24 hours) is marginal and amounts to between $4.5 \%$ in case of trips to Ukraine and $15 \%$ for the trips to Lithuania (Table 2). These values do not differ from the ones for trips to other neighbouring countries.

Table 2. Comparison of the number of times the border was crossed in outward travelling and the number of tourists in 2007 (in million)

\begin{tabular}{|l|c|c|c|}
\hline \multirow{2}{*}{} & \multirow{2}{*}{$\begin{array}{c}\text { Number of times } \\
\text { the border was } \\
\text { crossed }\end{array}$} & \multicolumn{2}{|c|}{ Tourists } \\
\cline { 3 - 4 } & & Number & $\begin{array}{c}\text { Share of tourists in } \\
\text { the total number of } \\
\text { persons travelling } \\
\text { abroad (in \%) }\end{array}$ \\
\hline Totals & 47.6 & 6.90 & 14.5 \\
\hline Germany & 16.8 & 1.55 & 9.23 \\
\hline Czechia & 12.3 & 0.40 & 3.25 \\
\hline Slovakia & 5.5 & 0.45 & 8.18 \\
\hline Ukraine & 5.6 & 0.25 & 4.46 \\
\hline Lithuania & 1.0 & 0.15 & 15.0 \\
\hline Russia & 0.7 & 0.05 & 7.14 \\
\hline Belarus & 0.7 & 0.05 & 7.14 \\
\hline
\end{tabular}

Source: own elaboration on the basis of data from GUS, the Border Guards and the Institute of Tourism.

As we compare the overall number of trips across the border and the tourist traffic in both directions, i.e. from Poland to the neighbouring countries and vice versa, we can state that the balance is dominated by the inward traffic from the neighbouring eastern countries (similarly as in the case of the border between Poland and Germany). Compared to other boundaries, at the eastern boundary the differences in the two-way the cross-border traffic and the tourist traffic are smaller in absolute numbers, but the ratios are higher (Figure 3 and 4). The ratio is the highest in the case of the tourist traffic between Poland and Ukraine (8.5 times more Ukrainians come to Poland than Poles go to Ukraine) and between Poland and Belarus (27 times in 2007 and 5.8 times in 2008). 


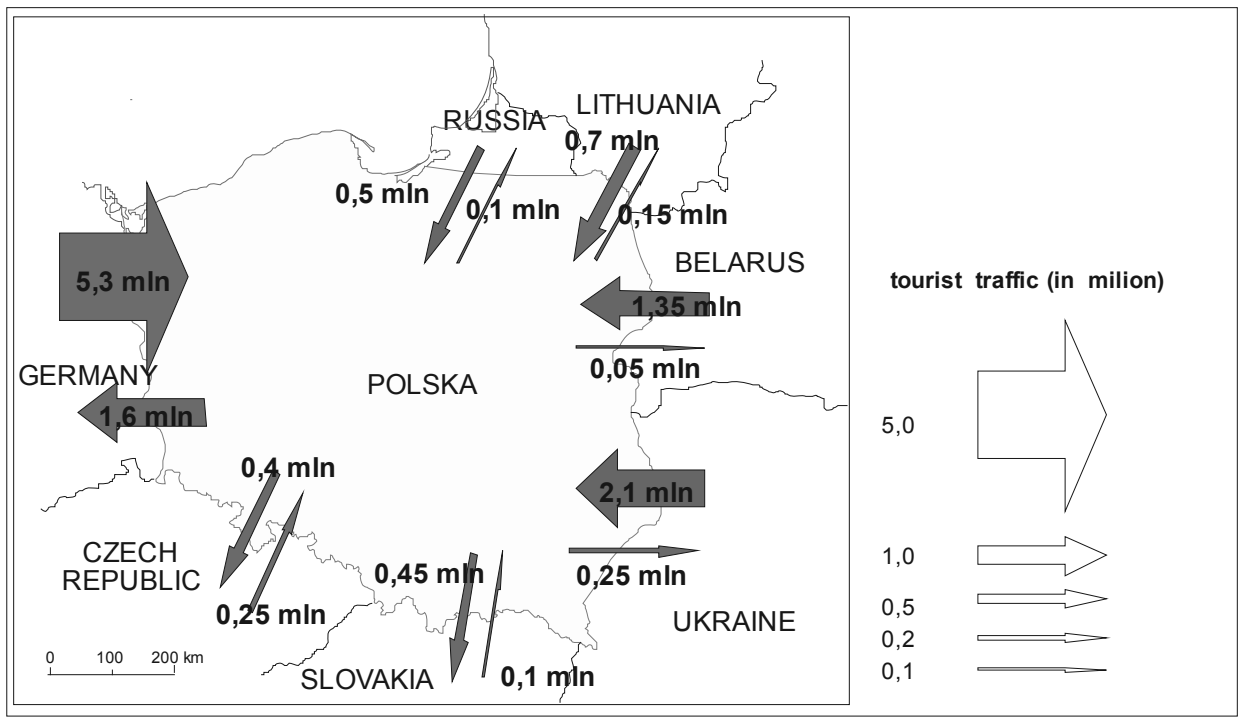

Figure 3. Intensity of the tourist traffic between Poland and particular neighbouring countries in 2007

Source: own elaboration on the basis of data from GUS, the Border Guards and the Institute of Tourism.

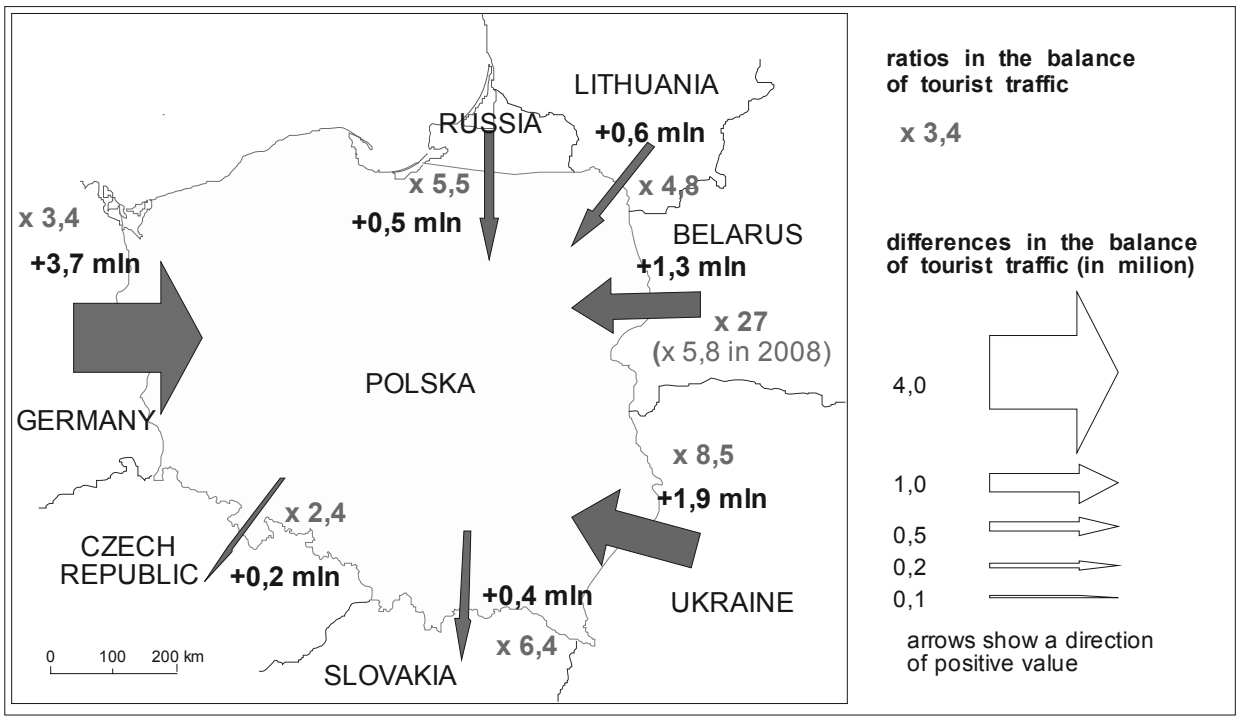

Figure 4. The differences and the ratios in the balance of tourist traffic between Poland and particular neighbouring countries in 2007

Source: own elaboration on the basis of data from GUS, the Border Guards and the Institute of Tourism. 


\section{DEVELOPMENT OF TOURISM ON THE AREAS NEIGHBOURING WITH THE OUTER BOUNDARY OF THE EUROPEAN UNION AND THE SCHENGEN ZONE}

Formation of a new transboundary space in the vicinity of the outer boundaries of the Schengen zone is quite difficult. The main barriers to the development of tourism are constituted on the areas neighbouring with the state boundaries first of all by poor transport-wise accessibility, shrinking resources (mainly the natural ones), lack or shortage of financial means, poor social capital (lack of leaders and of educated managing and servicing staff). Barriers are, of course, constituted also by the peripheral location and the vicinity of the state boundary, especially when this boundary features a closed character. Hence, the development of tourist space is theoretically more difficult within the border areas there, where the outer boundary of the European Union-and simultaneously the outer boundary of the Schengen zone-runs. This is undoubtedly due to a low number of border crossing points, low population density and poor infrastructure within the zone neighbouring upon the border (a couple, but even more than ten kilometres away from the border). Additional difficulties are associated with the specific segments of the border. In the Kaliningrad district important formal limitations have been introduced concerning the border zone. It is, in particular, forbidden to move over the Vistula Bar on the Russian side up to $7 \mathrm{~km}$ away from the state border, as well as up to $13 \mathrm{~km}$ from the point, where the boundaries of Poland, Lithuania and Russia come together (Palmowski 2007). The closed character of the Polish-Belarusian border, as well as the isolationist policy, conducted by the president of Belarus, contribute to difficulties in the social, economic and spatial contacts between the two countries. This entails also the difficulties in formation of common transboundary space, especially on the territory of the Białowieska Forest. There is just one border crossing point in that area, accessible for pedestrians, and the need of acquiring the Belarusian visa is an important obstacle to crossing the border. Although most of the accommodation facilities (especially hotels) in Białowieża offer an assistance in getting the visa, yet the waiting time for the visa, even though relatively short—only 3-4 days - makes it impossible to visit the Belarusian side for the Polish tourists, coming to these areas for a weekend. On the remaining areas, especially in the vicinity of the valley of Bug river, which also features the properties of the areas attractive for natureand culture-oriented tourism, development of tourism encounters also obstacles in the form of closed character of the border and low number of border crossing points. In numerous places (like in Włodawa) the bridges, destroyed during the World War II still do not exist and the situation is not improving. The Polish-Ukrainian border is also a closed one. Side by side with formal and political barriers there are a number of other ones, which gain special importance in the context of transboundary tourism. These are economic and social barriers. Within the Polish-Ukrainian borderland social barriers to transboundary cooperation are of special importance, including 
the negative historical experience, lack of psychological preparedness to cooperation, as well as differences in mentalities (Pisarenko 1998). Generally speaking, Ukrainians perceive Poles with greater sympathy than the other way around. Despite common history, similarity of cultures and languages, one can hardly speak of the feeling of identification with the transboundary region, among both Poles and Ukrainians. In the opinion of the majority of interviewees from Poland and all from Ukraine, the boundary remains the element dividing the two nations (Krok, Smętkowski 2006, p. 193). For the further development of the transboundary tourism it is essential to expand the infrastructure, encompassing, in particular, transport, accommodation and catering. There are, namely, on both Polish and Ukrainian sides, still a lot of serious shortcomings and insufficiencies with this respect, which might constitute a factor discouraging from mutual visits.

Tourist development within the borderland is dispersed (the main accommodation facilities are agro-tourist farms). There are no larger tourist centres. The border zone is less developed, also in terms of infrastructure, than the areas situated farther away from the border. On the side of the neighbours of Poland tourist infrastructure next to the border is relatively poor or nonexistent. The valuable areas of the eastern borderland, especially in terms of nature, are still poorly exploited from the point of view of tourism. Tourism makes little use of the transboundary opportunities. The current development takes place mainly owing to the European funds, and mainly on the Polish side. Tourism development on the Polish side appears to be getting nearer to the border. The closed border, but no longer the border zone, makes it possible to locate in its vicinity new infrastructure, on the areas previously not developed, including walking and bicycle routes, outlook towers etc. The majority of the new infrastructure is financed from the European Union means, which, interestingly, are directed to the development of the transboundary tourism. In practice, in no place this tourism, nor tourist space, have transboundary character.

As we analyse the functioning of tourism within the eastern borderland of Poland, we can reach the conclusion that development is difficult, and that for several reasons. The most important of them are:

- lack of tradition of tourism,

- poor infrastructure- the new one has a haphazard character,

- poor accessibility,

- development of tourism based solely on natural, or on cultural assets, which, on the areas devoid of tourist traditions, have essential difficulties with encouraging tourists to visiting,

- low adaptation capacities,

- very limited innovativeness,

- poor social capital. 


\section{SUMMARY AND CONCLUSIONS}

Tourism in the vicinity of eastern boundaries of Poland is generally characterised by poor tourism-related development and lack of tourist traditions, as well as low degree of recognition as tourist destination. Current development takes place primarily owing to the European funds and mainly on the Polish side of the border. Due to the process of change in the function of the boundaries and facilitation of procedures related to border crossing, an increase of flow of people followed. This increase is also motivated by the existence of differences between the neighbouring areas and the needs of people. The increase of cross-border and tourist traffic contributes to the emergence of new tourist developments and accompanying services. The main element of investments in the domain of tourism (especially leisure and natureoriented tourism) is currently constituted by the assistance funds from the European Union.

On the areas neighbouring upon the eastern boundaries of Poland tourism is poorly developed. The difficulty lies in the poor transport-wise accessibility and large distances to the centres that generate traffic. In the vicinity of the respective borders the socio-economic setting that might give rise to traffic, is weak. This leads to the need of income-related travelling, that is-associated with trade or jobs, and a part of tourist trips have multi-motivational character (e.g. tourism and trade). In the transboundary setting, tourism within the eastern borderland is based almost exclusively on the price differentials. These are both trade and transit, as well as short tourist visits.

The need of integrating European space, especially in the vicinity of the outer borders of the European Union calls for the political will of the neighbouring countries, as well as for significant financial outlays. Hence, such an integration and functioning of transboundary tourism on the area cut across by the outer boundary of the Schengen zone are even more difficult. The respective development is also made difficult by the growing competition, but given effective management, enhancement of attractiveness and increase of outlays into marketing, the border-adjacent areas might be developing better exactly owing to tourism. Transport routes and the network of tourist walking and bicycle tracks ought to be well matching and compatible. For a further development, especially of the transboundary tourism, opening of new border crossing points is indispensable. High importance ought also be attached to creation of common (transboundary) tourist information, and for purposes of international tourism - to development of a joint tourist offer.

\section{REFERENCES}

Boyd, S. (2004), National Parks: Wilderness and culture, in: Lew A., Hall M., and Williams A. (eds.), A Companion to Tourism, , Blackwell, Malden, 473-483.

Denisiuk, Z., Stoyko, S., and Terray, J. (1997), Experience in cross-border cooperation for national park and protected areas in central Europe, in: Nelson J. G. and Sera- 
fin R. (eds.) National parks and protected areas: Keystonses to conservation and sustainable development, Springer, Berlin, 145-150.

Eberhardt, P. (2004), Polska i jej granice. Z historii polskiej geografii politycznej, Wydawnictwo UMCS, Lublin.

Kałuski, S. (1993), Turystyka kwalifikowana jako czynnik rozwoju regionalnego obszarów przygranicznych Polski, Fundacja im. Friedricha Eberta, Warszawa.

Kałuski, S. (1994), The new eastern Polish border in the face of environmental and socio-political problems, in: Gallusser W. A. (eds.) Political Boundaries and Coexistence, Peter Lang, Bern, 57-64.

Krawczyk, B. (1999), Lecznicze i turystyczne zasoby Regionu Karpackiego (Ukraina), Obszary szczególnej troski i nowych możliwości rozwoju na przykładzie Polski i Ukrainy, EUROPA XXI, 3, 25-40.

Krok, K. and Smętkowski, M. (2006), Polsko-ukraińska współpraca transgraniczna, in: Gorzelak G. and Krok K., Nowe granice Unii Europejskiej—wspótpraca czy wykluczenie?, Wydawnictwo Naukowe Scholar, Warszawa.

Leiper, N. (1990), Tourist attraction systems. Annals of Tourism Research, 17, (3), 367-384.

Lew, A. (1987), A Framework of Tourist Attraction Research. Annals of Tourism Research, 14, (4), 553-575.

Meyer, B., (2001), Znaczenie turystyki transgranicznej w obszarach przygranicznych. in: Panasiuk A. (ed.) Sektor turystyczny w spoteczeństwie informacyjnym: turystyka, poczta, telekomunikacja, Wydawnictwo Uniwersytetu Szczecińskiego, Szczecin.

Miszczuk, A. (2007), Zewnętrzna granica Unii Europejskiej-Ukraina. Możliwości wykorzystania dla dynamizacji procesów rozwojowych, Ekspertyzy na potrzeby opracowania Strategii Rozwoju społeczno-gospodarczego Polski Wschodniej do roku 2020, MRR, Warszawa, 13-70.

Palmowski, T., (2007), Perspektywy rozwoju wspótpracy transgranicznej pomiędzy Obwodem Kaliningradzkim a pótnocno-wschodniq Polska, in: Fiedorow G. M., (ed.) Uwarunkowania rozwoju rosyjskiej i polskiej części euroregionu „Battyk”, Regiony Nadmorskie, 13, Uniwersytet Gdański, Gdynia-Pelplin, 152-208.

Pisarenko, S. (1998), Bariery społeczno-gospodarcze ukraińsko-polskiej wspótpracy transgranicznej, in: Kitowski J. (ed.) Czynniki i bariery regionalnej wspótpracy transgranicznej—próba syntezy, Rzeszów.

Potocki, J. (2009), Funkcje turystyki w ksztaltowaniu transgranicznego regionu górskiego Sudetów, Wydawnictwo WTN, Wrocław.

Pradeau, Ch. (1994), Jeux et enjeux des frontières, Presses Universitaires de Bordeaux.

Timothy, D. J. (2002), Tourism and Political Boundaries, Routledge Advances in Tourism, London-New York.

Przecławski, K. (1996), Człowiek a turystyka. Zarys socjologii turystyki, Alis, Kraków.

Rąkowski, G. (2000), Transgraniczne obszary chronione na wschodnim pograniczu Polski. Zakres koncepcji. Instytut Ochrony Środowiska, Warszawa, 97-140.

Richards, G. (2002), Tourism Attraction Systems, Annals of Tourism Research, 29, (4), 1048-1064.

Rykiel, Z. (1991), Rozwój regionów stykowych w teorii $i$ w badaniach empirycznych, 
Prace Habilitacyjne, Wydawnictwo PAN i Ossolineum, Wrocław-Warszawa-Kraków. Studzieniecki T. (2004), Turystyka transgraniczna—nowa forma turystyki międzynarodowej w Europie, in: Adamowicz M. and Bergier J. (eds.) Rozwój obszarów przygranicznych w kontekście funkcjonowania Euroregionów, PWSZ, Biała Podlaska, 173-182.

Young, L., Rabb, M. (1992), New park on the bloc: Hungary, Czechoslovakia and Austria must overcome obstacles to create Eastern Europe's first trilateral park, National Parks, 66 (1), 35-40.

Więckowski, M. (1998) Góry podzielone granica—o ochronie przyrody na pograniczu polsko-stowackim, in: Kuczkowski W. et al. (eds.), Ziemia 98, Rocznik Polskiego Towarzystwa Turystyczno-Krajoznawczego, Warszawa.

Więckowski, M. (2004), Przyrodnicze uwarunkowania ksztaltowania się polskoslowackich więzi transgranicznych, Prace Geograficzne, 195, IGiPZ PAN, Warszawa.

Więckowski, M. (2009), Development of the New tourist space in the Polish Borderland, in: Kovacs A. D. (ed.) Old and new borderlines/frontiers/margins, Discussion Papers Special, Hungarian Academy of Sciences Centre for Regional Studies, Pecs, 89-97. 
http://rcin.org.pl 